\title{
DEPRESSIVE SYMPTOMS AND ASSOCIATED FACTORS IN RESIDENTS LIVING IN LONG-TERM CARE FACILITIES FROM THE METROPOLITAN AREA OF BELO HORIZONTE
}

\author{
Sintomas depressivos e fatores associados em idosos \\ institucionalizados da região metropolitana de Belo Horizonte
}

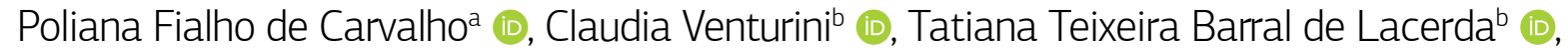

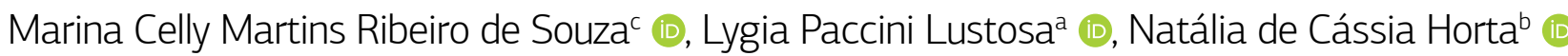

OBJECTIVE: To identify the presence of depressive symptoms and its association with self-rated health among older adults living in Long-term Care Facilities. METHODS: This is a cross-sectional study in which older adults living in LTCF were screened by using the Mental State Mini Exam. Standard questionnaires were used to collect the following data: 1) sociodemographic variables, 2) depressive symptoms, and 3) self-rated health. The descriptive statistical analysis by measures of central tendency and dispersion was performed to characterize the sample. The multinomial logistic regression analysis was performed to associate the variables. In all tests, the alpha value of 0.05 was considered. RESULTS: A total of 127 older adults living in 47 long-term care facilities were evaluated. Among those who presented depressive symptoms, 32.3\% were classified as having mild symptoms and $13.4 \%$ had severe symptoms. Regarding self-rated health, $46.5 \%$ considered it poor/very poor. In the analysis of the association between mild and severe depressive symptoms and self-rated health, statistical significance $(p=0.004$ and $p=0.001$, respectively) was found. CONCLUSIONS: The results of this study suggest that more attention should be directed to older adults living in LTCF who have symptoms of depression and to their impacts on the negative self-rated health.

KEYWORDS: aged; homes for the aged; depression.

OBJETIVO: Identificar a presença de sintomas depressivos e sua associação com a autopercepção de saúde em idosos residentes em instituições de longa permanência. METODOLOGIA: Estudo transversal que avaliou idosos institucionalizados após triagem realizada pelo miniexame do estado mental. Aplicaram-se questionários padronizados para a coleta de variáveis sociodemográficas, sintomas depressivos e autopercepção de saúde. Análise estatística descritiva por meio de medidas de tendência central e dispersão

○ foram realizadas para caracterização da amostra. Para associação entre as variáveis, realizou-se análise de regressão multinomial $\sum$ simples. Em todos os testes, considerou-se o valor de alfa igual a 0,05. RESULTADOS: Avaliaram-se 127 idosos residentes em 47 is instituições de longa permanência. Dentre aqueles que apresentaram sintomas depressivos, 32,3\% foram caracterizados como leves e 13,4\% com sintomas graves. Em relação à autopercepção de saúde, 46,5\% consideraram sua saúde ruim/muito ruim. Na análise da associação entre sintomas depressivos leves e graves e autopercepção de saúde, observou-se significância estatística de $p=0,004$ e $p=0,001$, respectivamente. CONCLUSÕES: Os resultados deste estudo sugerem a necessidade de atenção ao cuidado com os idosos institucionalizados que apresentam sintomas depressivos e seu impacto na autopercepção negativa da saúde. PALAVRAS-CHAVE: idoso; instituição de longa permanência para idosos; depressão.

\footnotetext{
aUniversidade Federal de Minas Gerais - Belo Horizonte (MG), Brazil. 'Pontifícia Universidade Católica de Minas Gerais - Belo Horizonte (MG), Brazil. cJersey College - Ewing (NJ), United States of America.
}

Correspondence data

Poliana Carvalho - Rua Gentil Diniz, 660 - Três Barras - CEP: 32041-120 - Contagem (MG), Brazil. E-mail: polianafcarvalho@gmail.com Received on: 06/26/2020 Accepted on: 08/25/2020

https://doi.org/10.5327/Z2447-212320202000078 


\section{INTRODUCTION}

In the early 2000s, Brazil became a country characterized by its middle-aged population, this aging being explained by the increase in life expectancy and the decrease in the fertility rate. ${ }^{1}$ According to data from the Brazilian Institute for Geography and Statistics (IBGE), in 2012, the Brazilian population aged 60 or over corresponded to $12.8 \%$. In 2019 , this number increased to $15.7 \%$ in Brazil and $16.7 \%$ in the state of Minas Gerais. ${ }^{2}$

The increase in the Brazilian population of older adults rapidly occurred and reflected in the increased demand for social assistance and healthcare services. The overload of services and the need for long-term care for older adults, due to their loss of functional independence and autonomy, often result in social isolation for these individuals, generally with decreased support for continuing family care. ${ }^{3}$

A survey conducted in 2010 showed that about 1\% of the older adult population in Brazil (84 thousand people) lives in long-term care facilities for older adults (LTCF); in the state of Minas Gerais, $0.8 \%$ live in LTCF. ${ }^{4}$ Most older adults living in these institutions are frailer. Nevertheless, the care provided for older people at LTCF is usually limited to shelter and food. ${ }^{5}$ Socially-isolated older people become more inactive and, consequently, with greater health problems. ${ }^{6}$ It is noteworthy that institutionalization increases vulnerability and the occurrence of depressive conditions. ${ }^{7}$

According to Bretanha et al., ${ }^{8}$ older adults who have more depressive symptoms are older, women, with poor self-rated health, single, and with low education level and income. According to the literature, the negative selfrated health is directly related to depressive symptoms, in addition to other factors such as the use of many medications, socioeconomic status, and personal relationships. ${ }^{7}$

Considering the need for understanding the symptoms of depression and the self-rated health of older adults living in LTCF in order to develop new strategies that favor health promotion and prioritize the maintenance of functionality, the objective of this study was to identify the presence of depressive symptoms and their association with self-rated health in residents who live in LTCF in the metropolitan area of Belo Horizonte (state of Minas Gerais, Brazil).

\section{METHODS}

This is a descriptive, observational, cross-sectional study that evaluated older adults living in LTCF in Belo
Horizonte and municipalities in the metropolitan area of Belo Horizonte (MABH) between September 2016 and July 2017. This study was approved by the Research Ethics Committee of Pontifícia Universidade Católica de Minas Gerais (PUC Minas), under protocol No. 817 (CAAE: 3147114.4 .0000 .5137$)$ and was funded by Conselho Nacional de Desenvolvimento Científico e Tecnológico (CNPq) (process No. 456804/2014-5) and by Fundo de Incentivo à Pesquisa (FIP) - PUC Minas (No. 1st/2017-378-S1).

The study unit was represented by LTCF and residents living in care homes. For sample calculation, simple random sampling in two stages was employed: first, the number of LTCF existing in the MABH that agreed to participate in the study was identified, and subsequently the number of older adults in each of these institutions. The sample included all MABH municipalities that agreed to participate and had at least one LTCF. Of the 170 LTCF existing in the MABH at the time of data collection, 156 agreed to participate in the research. Hence, according to the sample calculation, 44 institutions were selected, of which 28 were philanthropic and 16, private. In municipalities that had only one LTCF, such were automatically selected; in others with more than one LTCF, the number of LTCF was defined considering the proportion of older adults living in LTCF. Thus, considering the total of 625 older people residing in these instituitions at the time of the study; a $58 \%$ prevalence for quality of life, as assessed by the WHOQOL-BREF instrument (World Health Organization Quality of Life-Bref ), which was found based on a pilot study carried out by the research team on 23 older adults living in LTCF, a estimation error of $10 \%$, and a $90 \%$ confidence level, a minimum sample of 119 older people was established. The sample was calculated using the Stata software, version 12.0. Considering the fieldwork routines and the need for replacing LTCF that presented impediments to last-minute interviews, the final sample accounted for 47 LTCF.

The inclusion criteria were: aged over 60 years, not having cognitive impairment, as screened by the Mini Mental State Examination (MMSE), and having an interest in voluntarily participating in the study.

After selecting the LTCF, the resident was selected and an Informed Consent Form was obtained, followed by the application of the MMSE, the instrument used for screening. The employed cutoffs were those proposed by Bertolucci et al., ${ }^{9}$ taking into account the education level. 
Variables and measures

As for sociodemographic variables, the following were evaluated:

- sex (men or women);

- age, which was grouped into four groups (60-69, $70-79,80-89$, or > 90 years);

- marital status (single, married, widower, or divorced);

- time residing in the institution, categorized into four groups (up to 5 years, from 5 to 10 years, between 10 and 15 years, and > 15 years);

- education level (the following categories were established: illiterate, up to 8 years of formal education, from 8 to 14 years of formal education, and from 14 to 16 years of formal education).

Regarding depressive symptoms, the Geriatric Depression Scale (GDS-15) was applied, developed by Sheikh and Yesavage in 1986, which is widely used to identify symptoms of depression in older adults. The 15 items of the scale have good diagnostic accuracy, with adequate reliability, specificity, and sensitivity. It is a scale of easy application, considering its dichotomous format (yes/no). ${ }^{10}$ The result of 6 or more points indicates depressive symptoms, considering 6 to 10 points as mild symptoms and equal to or greater than 11 points, severe symptoms. ${ }^{11}$

Regarding self-rated health, individuals were asked: "How do you evaluate your health in general?", with five response alternatives (very poor, poor, fair, good, and very good). ${ }^{12}$

\section{Data analysis}

Analyses were performed using the Stata software (Stata Corporation, College Station, Texas) version 12.0, considering a $5 \%$ level of significance. The descriptive statistical analysis was carried out by measures of central tendency and dispersion in order to characterize the sample. The multinomial logistic regression analysis was performed to associate the variables. In all tests, the alpha value of 0.05 was considered.

\section{RESULTS}

The MMSE was applied to 328 older adults, and 201 of them failed it. Thus, the 127 older adults participants in the study lived in 47 LTCF, $62.20 \%$ of them were philanthropic, 20 were located in the city of Belo Horizonte, and 27 in other municipalities of the MABH. The average age of the evaluated individuals was $74.92 \pm$
8.85 years, and $51.18 \%$ of them were men. Table 1 shows the residents' sociodemographic variables.

According to the results, $54.34 \%$ of older adults did not have depressive symptoms, $32.28 \%$ had mild symptoms, and $13.38 \%$ had severe symptoms. Of those with depressive symptoms, $53.44 \%$ were women.

Regarding self-rated health, $53.54 \%$ reported that their health was very good/good and $46.46 \%$ said it was poor/very poor.

In the analysis of the association between mild depressive symptoms (GDS $=6-10)$ and self-rated health, statistical significance $(p=0.004)$ was observed. These results indicate that older people with fair/poor self-rated health were 3.23 times more likely to have mild depressive symptoms (GDS $=6-10$ ) than older adults with good/very good self-rated health, as verified in Table 2 .

Conversely, for older adults with severe depressive symptoms (GDS $=11-15)$, those with fair/poor selfrated health were 10.67 times more likely to have severe depressive symptoms than people with good/very good self-rated health, as demonstrated in Table 3.

Table 1. Sociodemographic characteristics of older adults living in long-term care facilities $(n=127)$.

\begin{tabular}{|c|c|}
\hline Variables & $\begin{array}{c}\text { Frequency } \\
\text { n (\%) }\end{array}$ \\
\hline \multicolumn{2}{|l|}{ Age (years) } \\
\hline $60-69$ & $41(32.28)$ \\
\hline $70-79$ & $47(37.01)$ \\
\hline $80-89$ & $31(24.41)$ \\
\hline Over 90 & $8(6.30)$ \\
\hline \multicolumn{2}{|c|}{ Marital status } \\
\hline Single & $55(43.30)$ \\
\hline Married & $21(16.54)$ \\
\hline Widower & $27(21.26)$ \\
\hline Divorced & $24(18.90)$ \\
\hline \multicolumn{2}{|c|}{ Institutionalization time (years) } \\
\hline $0 \mid-5$ & $88(69.29)$ \\
\hline $51-10$ & $22(17.32)$ \\
\hline $10 \mid-15$ & $7(5.52)$ \\
\hline Over 15 & $10(7.87)$ \\
\hline \multicolumn{2}{|c|}{ Education level (years) } \\
\hline 0 & $34(26.77)$ \\
\hline $1 \mid-8$ & $79(62.20)$ \\
\hline $8 \mid-14$ & $8(6.30)$ \\
\hline $14-16$ & $6(4.73)$ \\
\hline
\end{tabular}


Table 2. Multinomial logistic regression analysis with mild depressive symptoms as a dependent variable $(n=41$.

\begin{tabular}{|c|c|c|}
\hline \multirow{3}{*}{ Variables } & GDS & \multirow{3}{*}{ OR $(95 \% \mathrm{Cl})$} \\
\hline & $6-10$ & \\
\hline & $n(\%)$ & \\
\hline \multicolumn{3}{|l|}{ Marital status } \\
\hline Single & $18(43.90)$ & $1.00(-)$ \\
\hline Married/Common-law marriage & $11(26.83)$ & $2.22(0.75-6.55)$ \\
\hline Widower & 09 (21.95) & $0.91(0.33-2.48)$ \\
\hline Divorced/Separated & $03(7.32)$ & $0.30(0.08-1.18)$ \\
\hline \multicolumn{3}{|l|}{ Age group (years) } \\
\hline $60-69$ & $14(34.15)$ & $1.00(-)$ \\
\hline $70-79$ & 15 (36.59) & $1.03(0.41-2.63)$ \\
\hline $80-89$ & $11(26.83)$ & $1.05(0.37-2.92)$ \\
\hline Over 90 & $01(2.43)$ & $0.27(0.03-2.50)$ \\
\hline \multicolumn{3}{|l|}{ Education level (years) } \\
\hline 0 & $17(41.46)$ & $1.00(-)$ \\
\hline $11-8$ & $20(48.78)$ & $0.32(0.13-0.78)$ \\
\hline $8 \mid-14$ & $01(2.44)$ & $0.15(0.02-1.47)$ \\
\hline $14-16$ & $03(7.32)$ & $0.77(0.13-4.43)$ \\
\hline \multicolumn{3}{|l|}{ Self-rated health } \\
\hline Good/Very good & $17(41.46)$ & $1.00(-)$ \\
\hline Fair/Poor & $24(58.54)$ & $3.23(1.44-7.22)$ \\
\hline
\end{tabular}

GDS: 0-5 no symptoms; 6-10 mild symptoms; 11-15 severe symptoms; OR: Odds Ratio; IC95\%: intervalo de confiança de 95\%.

Table 3. Multinomial logistic regression analysis with severe depressive symptoms as a dependent variable( $\mathrm{n}=18)$.

\begin{tabular}{|c|c|c|}
\hline \multirow{3}{*}{ Variables } & GDS & \multirow{3}{*}{ OR $(95 \% \mathrm{Cl})$} \\
\hline & $11-15$ & \\
\hline & $\mathrm{n}(\%)$ & \\
\hline \multicolumn{3}{|l|}{ Marital status } \\
\hline Single & $9(50.00)$ & $1.00(-)$ \\
\hline Married/Common-law marriage & $2(11.10)$ & $0.91(0.16-5.14)$ \\
\hline Widower & $2(11.10)$ & $0.45(0.09-2.40)$ \\
\hline Divorced/Separated & $5(27.78)$ & $1.13(0.32-4.05)$ \\
\hline \multicolumn{3}{|l|}{ Age group (years) } \\
\hline $60-69$ & 7 (38.89) & $1.00(-)$ \\
\hline $70-79$ & $6(33.33)$ & $0.72(0.21-2.48)$ \\
\hline $80-89$ & $4(22.22)$ & $0.53(0.12-2.36)$ \\
\hline Over 90 & $1(5.56)$ & $0.50(0.05-4.90)$ \\
\hline \multicolumn{3}{|l|}{ Education level (years) } \\
\hline 0 & $4(22.22)$ & $1.00(-)$ \\
\hline $11-8$ & $12(66.66)$ & $0.75(0.20-2.73)$ \\
\hline $8 \mid-14$ & $2(11.11)$ & $1.30(0.18-9.48)$ \\
\hline $14-16$ & $0(0)$ & $0.00(-)$ \\
\hline \multicolumn{3}{|l|}{ Self-rated health } \\
\hline Good/Very good & $3(16.67)$ & $1.00(-)$ \\
\hline Fair/Poor & $15(83.33)$ & $10.67(2.77-41.07)$ \\
\hline
\end{tabular}

GDS: 0-5 no symptoms; 6-10 mild symptoms; 11-15 severe symptoms; OR: Odds Ratio; IC95\%: intervalo de confiança de 95\%. 


\section{DISCUSSION}

In the present study, most older adults lived in philanthropic LTCF, were men, aged between 70 and 79 years, and were single. In addition, they lived in the institution for less than five years and had education level of up to eight years of formal education. Those with mild (32.28\%) and severe (13.38\%) depressive symptoms had worse self-rated health.

As aforementioned, most of the participating institutions were philanthropic, with the majority of income for their maintenance provided by the residents and considered insufficient to do so, considering that most of them are retired, with monthly income of one minimum wage. These data reflect the census survey carried out by Camarano and Kanso, ${ }^{13}$ according to which $65.2 \%$ of Brazilian institutions are philanthropic.

Regarding sex, there is a predominance of men, which may have occurred due to the sample allocation bias, considering that older adults were selected regardless of sex. In addition, women show greater cognitive impairment. ${ }^{14}$ Thus, the eligibility criterion may have excluded older women from the study. In the census survey carried out in Brazil by Camarano and Kanso, ${ }^{13}$ a higher prevalence of women (57.3\%) was found among the total number of older adults living in LTCF, taking into account that women have a higher life expectancy range, about five to seven years more than men. ${ }^{15,16}$ Thus, the greater number of men in the present study may have influenced the results.

The average age in this study was $74.92 \pm 8.85$ years, and most of the older adults were single (43\%). Moreover, a minority of older adults lived in the institution for more than 5 years. Increased age, single marital status, and multiple morbidities are the main causes for the institutionalization of older adults. ${ }^{17,18}$ However, as for marital status, widowed older adults are more frequent in studies, ${ }^{19,20}$ because old age and widowhood are predictors of institutionalization. ${ }^{19}$

Low education level is also frequently reported when evaluating philanthropic institutions, such as in the present study, considering that most institutions were philanthropic and $62 \%$ of older adults had up to eight years of formal education, which is in line with the study conducted by Güths et al., ${ }^{19}$ in which $65 \%$ of individuals had up to four years of formal education (elementary school).

Regarding depression, there is a high percentage of depressive symptoms among the older adults evaluated. Depressive symptoms are commonly associated with the presence of multiple factors, such as poor health, abandonment, widowhood, and institutionalization, which are related to the forms of neglect and abandonment prior to institutionalization, but also within institutions, whether due to prejudices against older adults, the negative perspective of old age, or the infantilization and depersonalization of those who receive them..$^{21,22}$ Other studies have also demonstrated a high occurrence of depressive symptoms when evaluating residents living in LTCF in Brazilian municipalities., ${ }^{7} 23$ These authors point to institutionalization itself as one of the main factors of depression in older adults, ${ }^{23}$ associated with the difficulty in developing bonds and the lack of privacy as criteria that predispose to depression. ${ }^{7}$ In addition, the study of Damaceno et al. ${ }^{24}$ presents aspects that corroborate the social representation of care for older adults living in LTCF, associated with basic care, such as feeding, conversation, and bathing, diminishing them by disregarding important concepts, such as co-responsibility of the subject and encouraging autonomy, without managers' and professionals' consideration for older adults as active subjects in the care process, which can have repercussions in the manifestation of depressive symptoms.

Other studies available in the literature indicate that depressive symptoms are more frequent among women. In the present study, $53.44 \%$ of the older adults with depressive symptoms were women. This fact may be explained by the low level of estrogen, which increases the risk of depression in older women. ${ }^{25}$

Self-rated health is an important indicator of quality of life and is predictive of survival. It is worth noting that the way older adults deal with their health directly impacts behavior, way of living as well as their choices. ${ }^{26}$ In this study, $46.46 \%$ rated their health as poor/very poor, which is similar to the study performed by Guimarães et al. ${ }^{7}$, who evaluated older adults living in LTCF in the municipality of Jequié (state of Bahia, Brazil), where $61.5 \%$ of them rated their health likewise. Polypharmacy, precarious economic situation, and discontent with personal relationships are also criteria that interfere with negative self-rated health. ${ }^{7}$

In the performed analyses, marital status and age group were not associated with depressive symptoms, corroborating the findings of Guimarães et al., ${ }^{7}$ who also evaluated residents living in LTCF.

On the other hand, education level was associated with depressive symptoms, which was also observed in the epidemiological study of Borges et al..$^{27}$ carried out on community-dwelling older adults from Florianópolis. As expected, older adults with a high level of education have 
lower risk of presenting depressive symptoms, emphasizing that high level of education is a protective factor for the onset of depressive conditions.

Depressive symptoms were associated with poor/very poor self-rated health. According to the results, poor/very poor self-rated health increases the chances of mild depressive symptoms by 3.23 times than in individuals with good/ very good self-rated health. Conversely, older adults with negative self-rated health (poor/very poor) are 10.27 times more likely to have severe depressive symptoms. The study carried out by Ramos et al. ${ }^{28}$ who evaluated community older adults living in northern Minas Gerais, demonstrated that they were 2.12 times more likely to manifest depressive symptoms when the self-rated health was poor/very poor. For Borges et al., ${ }^{27}$ factors that influence the onset of depressive symptoms may interfere with self-rated health, or the very report of negative health.

\section{CONCLUSION}

The results of this study indicate that the presence of depressive symptoms is a frequent finding among older adults living in LTCF and that negative self-rated health is associated with the presence of these symptoms. Therefore, it is extremely important to know the variables that interfere with depressive symptoms in older adults, in such a way to make interventions to reduce symptoms as well as their complications. Furthermore, LTCF should be aware of the importance of using standardized instruments to help identify this condition.

Especially in the context of long-term care facilities, the adoption of initiatives for welcoming older people, from the moment of their admission - by making the environment friendly and concerning the relationship with family members of these people - to measures implemented to maintain physical and cognitive functionality and activities that impact quality of life may have repercussions on self-rated health and risks of depression. Moreover, the need for implementing measures in the macro-political context is highlighted, by carrying out actions established in the existing public policies on the care for older people and in the articulation of long-term care policies aimed at this population.

\section{CONFLICTS OF INTEREST}

The authors declare no conflicts of interest.

\section{FUNDING}

The study was funded by Conselho Nacional de Desenvolvimento Científico e Tecnológico (CNPq) (No. 456804/2014-5) and by Fundo de Incentivo à Pesquisa (FIP) - Pontifícia Universidade Católica de Minas Gerais (No. 1st/2017-378-S1).

\section{AUTHORS' CONTRIBUTION}

PC: conceptualization, data curation, investigation, writing — original draft, and writing — review and editing. CV: formal analysis, supervision, writing — original draft, writing review and editing. TTBL: conceptualization, formal analysis, funding acquisition, methodology, resources, writing — review and editing. MCMRS: conceptualization, writing — review and editing. LPL: supervision, writing — review and editing. $\mathrm{NCH}$ : conceptualization, funding acquisition, project administration, resources, writing — review and editing.

\section{REFERENCES}

1. Reis C, Barbosa L, Pimentel V. O desafio do envelhecimento populacional na perspectiva sistêmica da saúde. BNDES Setorial [Internet]. 2016 [access on Feb. 20, 2020];(44):87-124. Available from: https://web.bndes.gov.br/bib/jspui/handle/1408/9955

2. Instituto Brasileiro de Geografia e Estatística. Pesquisa Nacional por Amostra de Domicílios Contínua - PNAD Contínua [Internet]. Instituto Brasileiro de Geografia e Estatística; 2019 [access on Aug. 17, 2020]. Available from: https://www.ibge.gov.br/estatisticas/sociais/ populacao/17270-pnad-continua.html?edicao $=27258 \& t=$ resultados

3. Dutra RR, Vargas SC, Tornquist L, Tornquist D, Martins VA, Krug SF. et al. Refletindo sobre o processo de institucionalização do idoso. Revista de Epidemiologia e Controle de Infecção [Internet]. 2016 [access on Feb. 20, 2020];6(Supl.):1 -9. Available from: https:// online.unisc.br/seer/index.php/epidemiologia/article/view/8040 http://dx.doi.org/10.17058/reci.v1i1.8040
4. Camarano AA. Características das Instituicões de Longa Permanência para Idosos - Região Sudeste [Internet]. IPEA; 2010 [access on Feb. 20, 2020]. Available from: https://www.ipea.gov.br/portal/index php?option=com_content $\&$ view $=$ article $\&$ id $=6437 \% 3$ Acaracterist icas-das-instituicoes-de-longa-permanencia-para-idosos-regiaosudeste \& catid $=265 \% 3$ A2010 \& directory $=1$ \& Itemid $=1$

5. Freitas AF, Prado MA, Cação JC, Beretta D, Albertini S. Sarcopenia e estado nutricional de idosos: uma revisão da literatura. Ara Ciênc Saúde [Internet]. 2015 [access on Feb. 20, 2020];22(1):9-13. Available from: http://www.cienciasdasaude.famerp.br/index.php/racs/article/view/19 https://doi.org/10.17696/2318-3691.22.1.2015.19

6. Herbolsheimer F, Ungar N, Peter R. Why Is Social Isolation Among Older Adults Associated with Depressive Symptoms? The Mediating Role of Out-of-Home Physical Activity. Int J Behav Med [Internet]. 2018 [access on Feb. 20, 2020];25(6):649-57. Available from 
https://pubmed.ncbi.nlm.nih.gov/30350258/ https://doi.org/10.1007/ s12529-018-9752-x

7. Guimarães LA, Brito TA, Pithon KR, Jesus CS, Souto CS, Souza SJN, et al. Sintomas depressivos e fatores associados em idosos residentes em instituição de longa permanência. Ciênc Saúde Coletiva [Internet]. 2019 [access on Feb. 20, 2020];24(9):3275-82. Available from: http://www.scielo.br/scielo. php?script=sci_arttext\&pid=S1413-81232019000903275 http://dx.doi.org/10.1590/1413-81232018249.30942017

8. Bretanha AF, Facchini LA, Nunes BP, Munhoz TN, Tomasi E, Thumé E. Sintomas depressivos em idosos residentes em áreas de abrangência das Unidades Básicas de Saúde da zona urbana de Bagé, RS. Rev Bras Epidemiol [Internet]. 2015 [access on Feb. 20, 2020];18(1):1-12. Available from: https://www.scielo.br/ scielo.php?script=sci_arttext\&pid=S1415-790X2015000100001 http://dx.doi.org/10.1590/1980-5497201500010001

9. Bertolucci PHF, Brucki SMD, Campacci SR, Juliano Y. O miniexame do estado mental em uma população geral. Arq Neuropsiquiatr [Internet]. 1994 [access on Feb. 20, 2020];52(1):1-7. Available from: https://www.scielo.br/pdf/anp/v52n1/01.pdf https://doi.org/10.1590/S0004-282X1994000100001

10. Almeida OP, Almeida SA. Confiabilidade da versão brasileira da Escala de Depressão em Geriatria (GDS) versão reduzida. Arq Neuropsiquiatr [Internet]. 1999 [access on Feb. 20, 2020];57(2B):421-6. Available from: https://www.scielo.br/scielo.php?script=sci_abstract\&pid=S0004282X1999000300013\&Ing=en\&nrm=iso\&tlng=pt https://doi.org/10.1590/S0004-282X1999000300013

11. Frank MH, Rodrigues NL. Depressão, ansiedade, outros distúrbios afetivos e suicídio. In: Freitas EV, Py L, Cançado FAX, Doll J, Gorzoni ML, editores. Tratado de Geriatria e Gerontologia. Rio de Janeiro: Guanabara Koogan; 2006. p. 376-86.

12. Mantovani EP, Lucca SR, Neri AL. Autoavaliação negativa de saúde em idosos de cidades com diferentes níveis de bem-estar econômico: dados do Estudo FIBRA. Ciênc Saúde Coletiva [Internet]. 2015 [access on Feb. 20,20201:20(12):3653-68. Available from: https://www.scielo.br/scielo php?pid=S1413-81232015001203653\&script=sci_abstract\&tlng=pt https://doi.org/10.1590/1413-812320152012.20492014

13. Camarano AA, Kanso S. As Instituições de Longa Permanência para Idosos no Brasil. Rev Bras Estud Popul [Internet]. 2010 [access on Feb. 20, 2020];27(1):233-5. Available from: https://www.scielo.br/scielo. php?pid=S0102-30982010000100014\&script=sci_arttext\#: : :text=0\%20 que\%20\%C3\%A9\%20uma\%20institui\%C3\%A7\%C3\%A3o,da\%20aus\% C3\%AAncia\%20de\%20pol\%C3\%ADticas\%20p\%C3\%BAblicas https://doi.org/10.1590/S0102-30982010000100014

14. Argimon IIL, Lopes RMF, Terroso LB, Farina M, Wendt G, Esteves CS. Gênero e escolaridade: estudo através do miniexame do estado mental (MEEM) em idosos. Aletheia [Internet]. 2012 [access on Feb. 20, 2020];(38-9):153-61. Available from: http://pepsic.bvsalud.org/scielo.php?script=sci arttext\&pid=S1413-03942012000200012

15. Almeida AV, Mafra SCT, Silva EPD, Kanso S. A Feminização da Velhice: em foco as características socioeconômicas, pessoais e familiares das idosas e o risco social. Textos Contextos [Internet] 2015 [access on Feb. 20, 2020];14(1):1 15-31. Available from: http:// dx.doi.org/10.15448/1677-9509.2015.1.19830

16. Araújo AM, Sousa Neto TB, Bós AJG. Diferença no perfil de idosos institucionalizados, em lista de espera e que não desejam a institucionalização. Rev Bras Geriatr Gerontol [Internet]. 2016 [access on Feb. 20, 2020];19(1):105-18. Available from: https:// www.scielo.br/scielo.php?script=sci arttext\&pid=S1809$98232016000100105 \&$ Ing $=$ pt\&nrm=iso\&tlng=pt http://dx.doi.org/10.1590/1809-9823.2016.14175

17. Ferreira RDM, Colombo LC, Carneiro TLS, Silva BF, Gimenez GS. Prevalência de depressão em idosos institucionalizados no interior de Rondônia, Brasil. Rev Eletrônica FACIMEDIT [Internet]. 2018 [access on Feb. 20, 2020];7(1):62-74. Available from: http://repositorio. facimed.edu.br/xmlui/handle/123456789/77
18. Azevedo LM, Lima HHG, Oliveira KSA, Medeiros KF, Gonçalves RG, Nunes VM, et al. Perfil sociodemográfico e condições de saúde de idosos institucionalizados. Rev Bras Pesq Saúde [Internet]. 2017 [access on Feb. 20, 2020];19(3):16-23. Available from: http:// periodicos.ufes.br/RBPS/article/view/19560

19. Güths JFS, Jacob MHV, Santos AMPV, Arossi GA, Béria JU. Perfil sociodemográfico, aspectos familiares, percepção de saúde, capacidade funcional e depressão em idosos institucionalizados no Litoral Norte do Rio Grande do Sul, Brasil. Rev Bras Geriatr Gerontol [Internet]. 2017 [access on Feb. 20, 2020];20(2):17585. Available from: https://www.scielo.br/scielo.php?pid=S1809$98232017000200175 \&$ script $=$ sci arttext\&tlng $=p t$ https://doi.org/10.1590/1981-22562017020.160058

20. Fluetti MT, Fhon JRS, Oliveira AP, Chiquito LMO, Marques S. Síndrome da fragilidade em idosos institucionalizados. Rev Bras Geriatr Gerontol [Internet]. 2018 [access on Feb. 20, 2020];21(1):62-71. Available from: https://www.scielo.br/pdf/rbgg/v21n1/pt_18099823-rbgg-21-01-00060.pdf https://doi.org/10.1590/198122562018021.170098

21. Hartmann Júnior JAS, Gomes GC. Depressão em idosos institucionalizados: as singularidades de um sofrimento visto em sua diversidade. Rev SBPH [Internet]. 2014 [access on Feb. 20, 2020];17(1):83-105. Available from: http://pepsic.bvsalud.org/scielo. php?script=sci_arttext\&pid=S1516-08582014000200006

22. Poltronieri BC, Souza ER, Ribeiro AP. Violência no cuidado em instituições de longa permanência para idosos no Rio de Janeiro: percepções de gestores e profissionais. Saúde Soc [Internet]. 2019 [access on Feb. 20, 2020];28(2):215-26. Available from: https://www.scielo.br/scielo. php?pid=S0104-1290201900020001 $7 \&$ script=sci_arttext\&tlng=p https://doi.org/10.1590/s0104-12902019180202

23. Matos AIP, Mourão I, Coelho E. Interação entre a idade, escolaridade, tempo de institucionalizacão e exercício físico na funcão cognitiva e depressão em idosos. Motricidade [Internet]. 2016 [access on Feb. 20, 2020];12(2):38-47. Available from: http://www.scielo.mec. pt/scielo.php?script=sci_arttext\&pid=S1646-107X2016000200006 http://dx.doi.org/10.6063/motricidade.6805

24. Damaceno DG, Chirelli MQ, Lazarini CA. A prática do cuidado em instituições de longa permanência para idosos: desafio na formacão dos profissionais. Rev Bras Geriatr Gerontol [Internet] 2019 [access on Feb. 20, 2020];22(1):e180197. Available from: https://www.scielo.br/scielo.php?script=sci_arttext\&pid=S180998232019000100206\&lng=en\&nrm=iso\&tlng=pt http://dx.doi.org/10.1590/1981-22562019022.180197

25. Hellwig N, Munhoz TN, Tomasi E. Sintomas depressivos em idosos: estudo transversal de base populacional. Ciênc Saúde Coletiva [Internet]. 2016 [access on Feb. 20, 2020];21(11):357584. Available from: https://www.scielo.br/scielo.php?pid=S1413$81232016001103575 \&$ script $=$ sci abstract\&tlng=pt http://dx.doi.org/10.1590/1413-812320152111.19552015

26. Silva IT, Pinto Junior EP, Vilela ABA. Autopercepção de saúde de idosos que vivem em estado de corresidência. Rev Bras Geriatr Gerontol [Internet]. 2014 [access on Feb. 20, 2020];17(2):275-87. Available from: https://www.scielo.br/scielo. php?script $=$ sci_arttext\&pid=S1809-98232014000200275 https://doi.org/10.1590/S1809-98232014000200006

27. Borges LJ, Benedetti TRB, Xavier AJ, d'Orsi E. Fatores associados aos sintomas depressivos em idosos: estudo EpiFloripa. Rev Saúde Pública [Internet]. 2013 [access on Feb. 20, 2020]:47(4):70110. Available from: https://www.scielo.br/scielo.php?script=sci_ arttext\&pid=S0034-89102013000400701\&lng=pt\&nrm=iso http://dx.doi.org/10.1590/S0034-8910.2013047003844

28. Ramos GCF, Carneiro JA, Barbosa ATF, Mendonça JMG, Caldeira AP. Prevalência de sintomas depressivos e fatores associados em idosos no norte de Minas Gerais: um estudo de base populacional. J Bras Psiquiatr [Internet]. 2015 [access on Feb. 20, 2020];64(2):122-31. Available from: https://www.scielo.br/scielo. php?pid=S0047-20852015000200122\&script=sci_abstract\&tlng=pt https://doi.org/10.1590/0047-2085000000067 